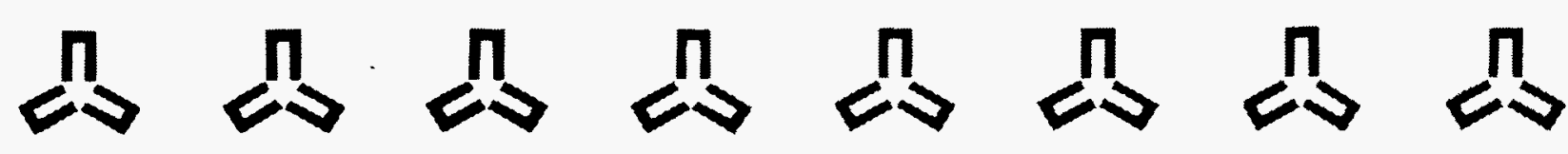

MLM-MU-91-65-0005

$\ln _{0}$

RECEIVED

$\stackrel{n}{n}$

JUL 011996

OSTI<smiles>C1=CC=C1</smiles>

QUALITY ASSURANCE PLAN

FOR

SITE ELECTRICAL REPLACEMENTS AND SUBSTATION LINE ITEM SUBPROJECT: $69 \mathrm{KV}$ SUBSTATION

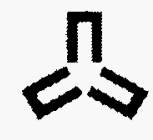

$\stackrel{n}{2}$

May 21, 1991
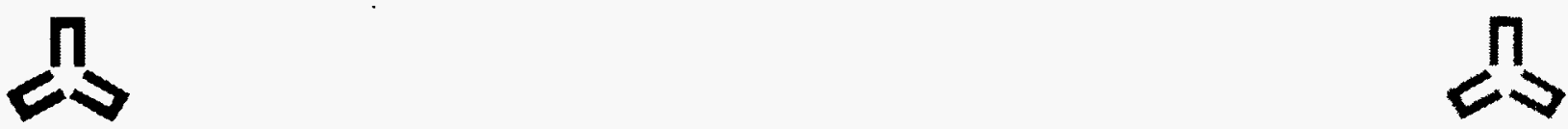

$\sum_{2}^{n}$

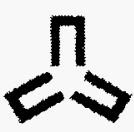

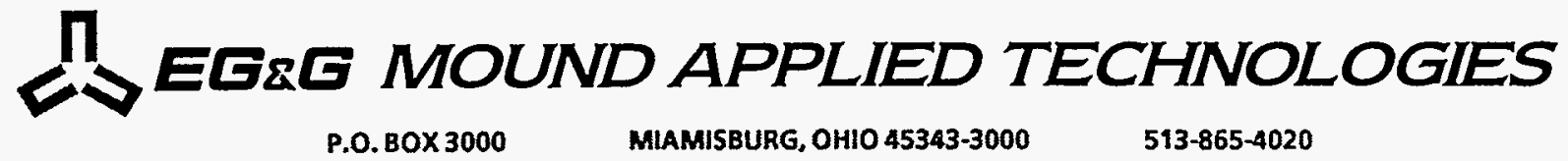

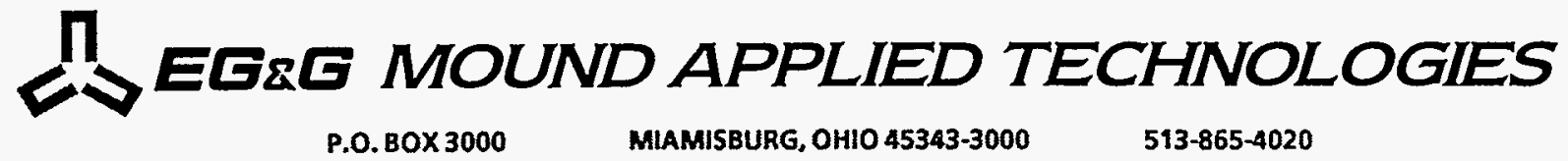

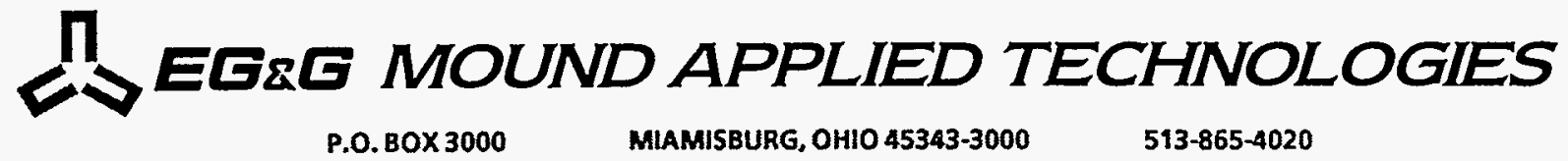

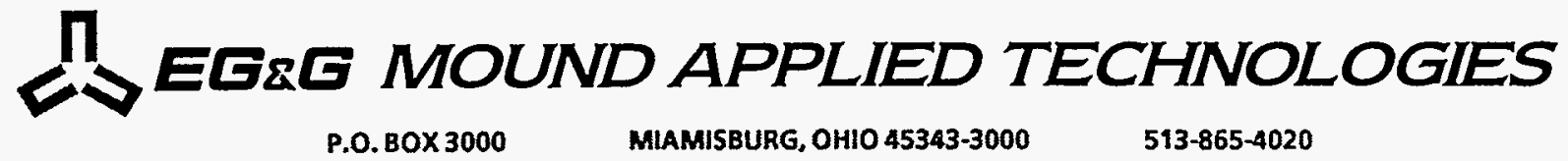

operated for the UNITED STATES DEPARTMENT OF ENERGY
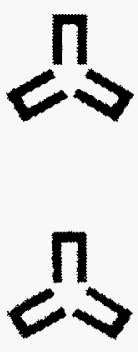

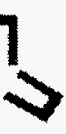

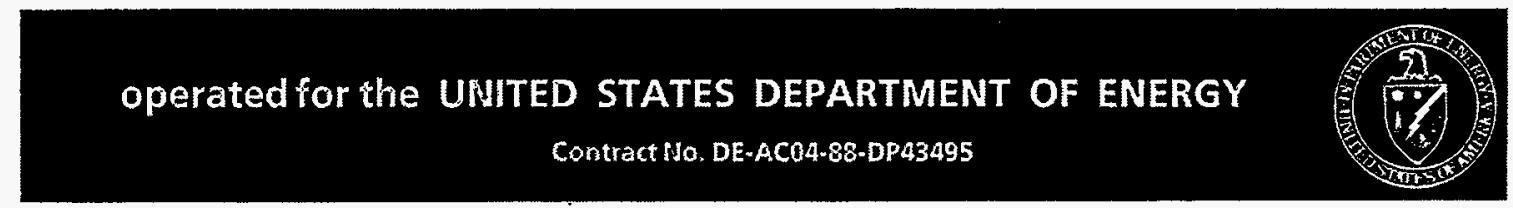




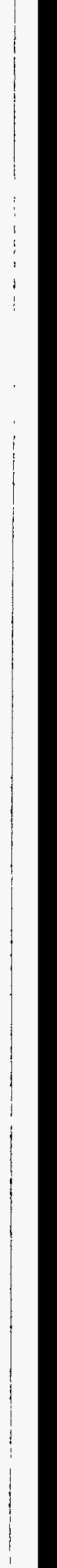




\title{
DISCLAIMER
}

This report was prepared as an account of work sponsored by an agency of the United States Government. Neither the United States Government nor any agency thereof, nor any of their employees, makes any warranty, express or implied, or assumes any legal liability or responsibility for the accuracy, completeness, or usefulness of any information, apparatus, product, or process disclosed, or represents that its use would not infringe privately owned rights. Reference herein to any specific commercial product, process, or service by trade name, trademark, manufacturer, or otherwise does not necessarily constitute or imply its endorsement, recommendation, or favoring by the United States Government or any agency thereof. The views and opinions of authors expressed herein do not necessarily state or reflect those of the United States Government or any agency thereof.

\section{QUALITY ASSURANCE PLAN}

for

Site Electrical Replacements and Substation Line Item

\author{
Subproject: $69 \mathrm{KV}$ Substation
}

Project AES No. M82742

Issue of May 21, 1991

Prepared by: C. K. Ohler

$\because$

EG\&G Mound Applied Technologies

Miamisburg, Ohio

Approvals:

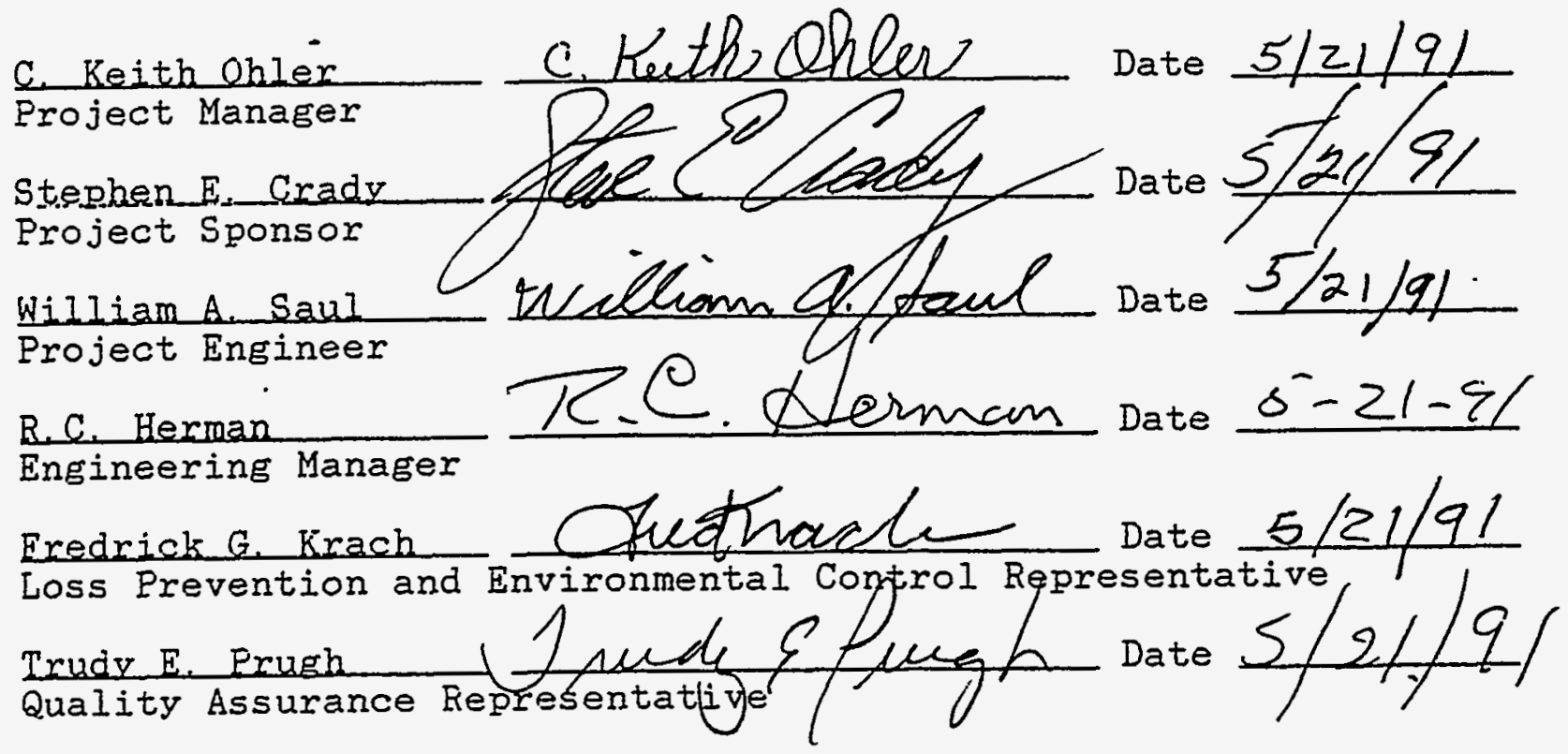



QA Plan for Site Electrical Replacements and Substation Project

Table of Contents

page

1. Description and Scope of Project .............. 1

2. Purpose of QA Plan ........................ 1

3. Applicable Documents ..................... I

4. Analysis of Consequence of Failure ............. 3

5. Quality Elements and Quality Assurance Efforts ...... 3

5.1. Organization .................... 3

5.2. Quality Assurance Program ............... 5

5.3. Design Control .................... 6

5.4. Procurement Document Control .............. 7

5.5. Instructions, Procedures, and Drawings ........ 7

5.6. Document Control .................... 8

5.7. Control of Purchased Items and Services ....... 9

5.8. Identification and Control of Items .......... 9

5.9. Control of Processes .................. 9

5. 10. Inspection $\ldots \ldots \ldots \ldots \ldots \ldots \ldots \ldots \ldots \ldots \ldots \ldots \ldots \ldots \ldots$

5.11. Test Control ..................... 10

5.12. Control of Measuring and Test Equipment ....... 11

5.13. Handling, Storage, and Shipping .......... 11

5.14. Inspection, Test, and Operating Status ......... 12

5.15. Control of Nonconforming Items ............ 12

5.16. Corrective Action ......................... 13

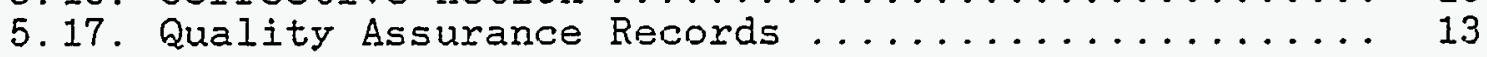

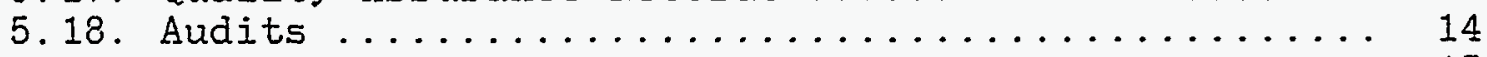

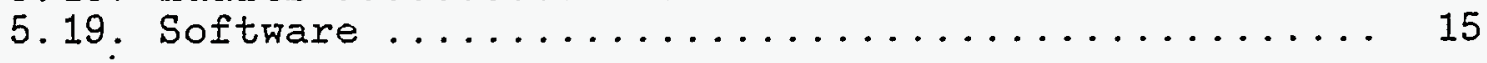

Appendix A. Quality Assurance Element Matrix

Appendix B. Project Quality Assurance Review 



\section{QA Plan for $69 \mathrm{KV}$ Susbstation Project - Page 1}

\section{Description and Scope of Project}

The $69 \mathrm{KV}$ Substation Project is based on the recognized need to provide a continuous, reliable source of power and to improve the firm capacity of the electrical service to all production facilities at Mound.

The project consists of the following major element:

\section{$69 \mathrm{KV}$ Substation:}

1. Install a $69 \mathrm{KV}$ Substation and associated equipment with two parallel 18 MVA transformers.

2. Install duct bank as required and provide $15 \mathrm{KV}$ feeder cable from new substation to existing Substation 95 for connection to Mound's existing primary distribution system.

3. Install duct bank for underground routing of the $15 \mathrm{KV}$ feeder cable from Manhole $5 \mathrm{C}$ to the existing power house cable pit.

4. Reconfigure existing Dayton Power and Light Co. $15 \mathrm{KV}$ switchgear in $P^{\prime}$ Building.

\section{Purpose of QA Plan.}

The purpose of this Quality Assurance Plan (QA P.lan) is to assure that the objectives of the United States Department of Energy (D.O.E.) and EG\&G Mound Applied Technologies, Miamisburg, . Ohio (Mound) are met for this non-weapons project relative to health and safety, protection of the environment, reliability and continuity of operations, and documentation of quality efforts. This QA PIan identifies the activities and responsibilities which are necessary in the design, procurement, fabrication, installation, and start up of this project in order to meet these objectives.

\section{Applicable Decuments}

The D.O.E. requirements for quality assurance for projects such as this one are set forth in AL Order 5700.6B, Revision 2, dated July 7, 1989. That AI Order directs contractors such as Mound to develop non-weapons quality assurance programs through application of appropriate requirements of the consensus standard of the American Society of Mechanical Engineers (ASME) titled "Quality Assurance Program Requirements for Nuclear Eacilities". That standard is designated as ASME NQA-1-1989 Edition and is commonly called "NQA-1". A set of 1989 addenda have been issued. 


\section{QA Plan for $69 \mathrm{KV}$ Substation Project - Page 2}

The Mound non-weapons quality assurance program reflecting the D.O.E. guidance cited above is presented in Mound Technical Manual MD-10165. The implementation of that program within the Engineering Department is set forth in Mound Technical Manual MD-10241, titled "5700.6B Quality Plans for Engineering Department" (Manual MD-10241).

Other Documents and Forms:

Mound Manual MD-10286, titled "Safety and Hygiene Manual".

Mound Systems Manual 804, titled "Mound Project Management Manual 804", (Manual 804) provides procedures for major or construction capital projects.

Mound System Manual 808, titled "General Requirements for $A-E$ Work".

Mound System Manual 810, titled "Master Construction Specifications".

Mound Systems Manual No. 811, titled "Mound Engineering Department AES System Manual", (AES Manual) provides procedures for managing and documenting expense, capital equipment, productivity capital, and reimbursable projects.

Mound SPA-891214, titled "Drawing Control Procedures", describes the Mound drawing control system.

Mound Form MI-8440, titled "Project Quality Assurance Review".

Mound Form ML-7588, titled "Engineering Review Transmittal Sheet".

Mound Form ML-8816, titled "Engineering Department Nonconformance Report".

National Fire Protection Association, NFPA 70, 1990 titled "National Electrical Code".

Institute of Electrical and Electronic Engineers, ANSI/IEEE 80,1986 , titled "Guide for Safety in Substation Grounding".

Institute of Electrical and Electronic Engineers, ANSI/IEEE C2, 1990, titled "National Electrical. Safety Code".

Institute of Electrical and Electronic Engineers, ANSI/IEEE C37, 1989, titled "Circuit Breakers, Switchgear, Relays, Substations \& Fuses". 
QA Plan for $69 \mathrm{KV}$ Substation Project - Page 3

Institute of Electrical and Electronic Engineers, ANSI/IEEE C57, 1990, titled "Distribution Fower and Regulating Transformers".

Institute of Electrical and Electronic Engineers, ANSI/IEEE 141, 1986, titled "Recommended Practice for Electric Power Distribution for Industrial Plants".

Institute of Electrical and Electronic Engineers, ANSI/IEEE 837, 1989, titled "Standards for Qualifying Permanent Connections used in Substation Grounding".

\section{Analysis of Consequence of Failure.}

A Project Quality Assurance Review was completed and approved on December 18, 1990. The Project Manager, together with. the Project Sponsor, the Project Engineer, the LP\&EC Representative, and the QA Representative participated in the analysis of the potential failure modes and associated consequences. The projects most severe QA Level as defined in Section 1.3 of Manual MD-10241, was Quality Level 1. Manual MD-10241 requires a written QA Plan for any AES project assessed as QA Level 1.

The major considerations in determining the QA LeveI were the risks of injury, loss of life; and loss of equipment greater than $\$ 500,000$ that may ensue if proper design, installation, and testing techniques/procedures are not followed for the $69 \mathrm{KV}$ substation, and high voltage cable installation. The problem in these areas would not be discovered until the system is energized.

\section{Quality Elements and Quality Assurance Efforts}

The quality assurance efforts planned for this project are explicitly discussed in the following sections (5.1 through 5.19). The first 18 section headings are the same as those of the basic requirements, or elements, of both ASME NQA-1-1989 Edition and D. O. E Order AL 5700.6B, Revision 2. The 19th section is for software.

\subsection{Organization}

Responsibility for the non-weapons quality assurance program at Mound is vested with the Director of the Quality Department. OveraIl administration of the program is delegated to a staff individual reporting to the Manager of Non-weapons Quality Assurance. Implementation of the program is conducted by a 


\section{QA Plan for $69 \mathrm{KV}$ Substation Project - Page 4}

"matrix" organization involving Department Coordinators from the various departments.

Within the Engineering Department, the NWQA Program Manager manages the NWQA program. The NWQA Program Manager reports to the Manager of Engineering Systems and Design, who in turn reports to the Director of Engineering. A staff of Section NWQA Specialists report directly to the NWQA Program Manager and implement the program in their Section. Thus the NWQA staff is administratively independent of all other direct supervision. Refer to Figure 1 for the $69 \mathrm{KV}$ Substation Project Matrix Organization Chart.

Those persons prominently associated with implementation of this QA PIan for the Site Electrical Replacements and Substation project are listed below together with their functional title and general responsibilities.

Project Sponsor. Stephen E. Crady - Responsible for participating in development of statement of work and design criteria; interpreting project requirements; approving project designs; participating in design reviews; providing technical support for project design, construction, and testing; providing start-up plans; and execution of this QA Plan.

Project Engineer. William A. Saul - Responsible for project design and technical guidance; developing material and equipment specifications; participating in design reviews; approving project designs; reviewing inspection and testing documentation; resolving nonconformance issues; controlling nonconforming. items; and maintaining QA records. Responsible for execution of this QA Plan.

Project Managex. C. Keith Ohler - Responsible for overall planning, engineering, and construction; in concurrence with the Project Sponsor and Project Engineer maintaining both technical and administrative control of the project; establishing project objectives; approving project designs; participating in design reviews; establishing and maintaining a project information, planning, and control system; coordinating all budget, finance, costs, schedules, and technical reporting; and developing/controlling Quality Assurance Program.

Construction Manager. Robert I. Stanley - Responsible for control of construction, administration of inspections, resolution of nonconformance, control of nonconforming items, and maintenance of $Q A$ records. Responsible for execution of this QA Plan.

Construction Inspector. David C. Weimer - Responsible for construction inspection, verification, and validation to assure compliance with design documentation. 


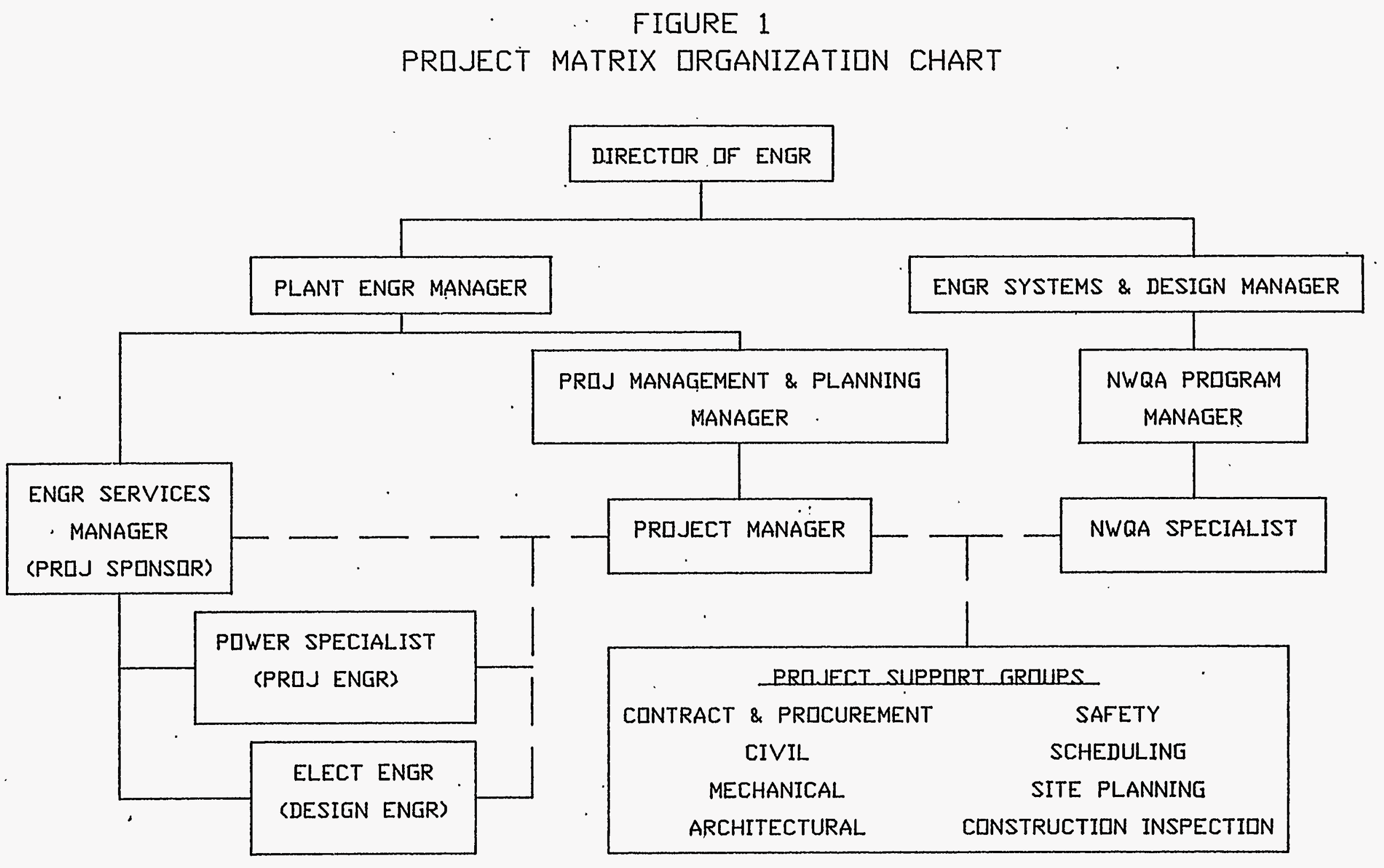





\section{QA Plan for $69 \mathrm{KV}$ Substation Project - Page 5}

Design/Build Engineering Firm. - Responsible for design; testing; specifications; training; drawings; design reviews; equipment procurement; subcontractor negotiations and control; scheduling; conformance to specifications and testing; conformance to safety; development, implementation and control of EG\&G Mound approved Quality Assurance Program; construction; and construction inspection.

Design Reviewers. Technical peer review of design.

William J. Lyons - Electrical.
Larraine Kapka (or designee) - HVAC.
David Heitz (or designee) __ - Eire Alarm Systems.

Technical Consultant. Robert H. Bryan - Technical advisory role for design, maintenance and training requirements of the project.

LP\&EC Representative. Fredrick G. Krach - Representative of Loss Prevention and Environmental Coñtrol (LP\&EC) with review and advisory role.

Drawing Control Supervisor. Arthur Kellex - Responsible for policy and administration of drawing control.

Material Ceordinator. Design/Build Eirm - Responsible for control of items in the material staging area.

QA Representative. Trudy E. Prugh - Representative of Nonweapon Quality Assurance. Responsible for review of this QA Plan and any internal Engineering audit of this project.

\subsection{Quality Assurance Program}

The non-weapons quality program plan for the Engineering' Department at Mound is described in Mound Technical Manual MD-10241, titled "5700.6B Quality Plans for Engineering Department". (Refer to Section 3 above for a discussion of the relation of Manual MD-10241 to Manual MD-10165, to D.O.E. Order AL 5700.6B, Revision 2, and to ASME NQA-1-1989 Edition.) This QA Plan for the $69 \mathrm{KV}$ Substation Project describes the specific implementation for this project of the guidance in Manual MD- 10241.

This Quality Assurance Plan is the minimum guidance document to address all quality elements as identified in MD-10241. A separate Quality Assurance Plan, as outlined in the Design. Criteria Document, will be written by the Design/Build Firm detailing specific quality assurance requirements. The D/B plan will be submitted for approval to EG\&G. Mound Personnel as a part of the Title I Design Package. 


\subsection{Design Contrel}

Explicit design criteria will be developed. Design information will be documented in the form of specifications and drawings. These documents will be used as communication tools to assure that items can be constructed, fabricated, inspected and tested according to definite design intent.

All electrical design considerations for this project will be in compliance with the appropriate DOE, Mound, ANSI/IEEE and NEPA standards as defined in Section 3 .

Al.I structural design considerations will be in compliance with recognized engineering standards.

Design/Build (D/B) Engineering Firm.

The $D / B$ Contractor will be responsible for designing the project to explicit criteria. Design information, specifications, drawings, and calculations will be presented, reviewed, and verified for design intent on a regular basis.

All design information, specifications, drawings, and calculations will be formally reviewed with appropriate EG\&G Personnel during specified design review meetings. The number and timing of the reviews will be controlled and are at the discretion of the $D / B$ Eirm. However, minimum formal design reviews will be conducted prior to submission of Title I and II. The results of all reviews and corrective action will be documented and maintained as permanent project records.

\section{EG\&G.}

All issues of drawings will be checked by. drafting for accuracy and proper format. In accordance with Section 1800; titled " Project Review", of Manual 804, design information, specifications, drawings, and calculations will be circulated by the Project Engineer for review and comment. Design documents will he reviewed independently by a peer Design Reviewer to assure the technical adequacy and safety of the design. Design documents will be reviewed by the Sponsor to confirm that the design criteria are satisfied, and by the LF\&EC Representative to assure the safety of the design. Reviews and comments designated by the reviewer as requiring response will be documented by completed Engineering Review Transmittal Sheets. The Project Engineer is responsible for resolving any review comments.

Engineering flow diagrams and wiring schematics will be checked against finished systems and changed, if necessary, so that the latest issue shows the system as constructed. Any such changes will take "field" changes into account.

Changes in the design documents will be controlled as described in Section 5.6 below. 


\section{QA Plan for $69 \mathrm{KV}$ Substation Project - Page 7}

Prior to transfer of the system to Electrical Maintenance, a list of the design drawings and other documentation will be compiled. This list will show the latest issue of each drawing.

\subsection{Procurement Document Control}

Procurement documents will be controlled in accordance with the Contracting and Procurement Systems Manual 701 . Purchase requisitions for Procurement Level 1 items as specified in Title I Design will be controlled in accordance with Section 1.5.4 of Manual MD-10241. All Level 1 procurement items will be identified and Iisted in the Design/Build Quality Assurance Plan.

Procurement will be executed by the Design/Build (D/B) Firm with detailed reviews by Mound personnel. All specifications for equipment to be purchased will be reviewed for inclusion of Mound and DOE requirements, codes, and standards. Specifically, the Project Engineer, and others that he so designates, will review the procurement documents for inclusion of the requirements of The Mound Master Specifications, ANSI C57 (transformers), ANSI C.37 (switchgear), NEPA 70 (National Electric Code), and other applicable documents as specified in the Design Criteria and or Section 3 of this document.

Inspection of equipment before shipment will be done by Mound and $D / B$ personnel. As appropriate, the procurement documents will include requirements for right of access by Mound and $D / B$ personnel to vendor's shop during selected fabrication, inspection, and testing stages.

'Procurement will be complete upon submittal of satisfactory final acceptance testing and or performance data as defined in the procurement document, and final written approval by Mound and $D / B$ personnel.

Note: AII subcontracting procurement shall meet the same requirements as specified above.

\subsection{Instructions, Procedures, and Drawings}

All instructions, procedures, and drawings will be prepared and maintained through construction by the Design/Build (D/B) firm.

Mound personnel will review all instructions, procedures, and drawings for compliance with requirements defined in Plant Engineering Manual 808 "General Requirements for A-E Work", the project Design Criteria, the Project Management Plan, MLM-MU-69-0006, Drawing Control Procedures, SPA891214, and Mound MD-10286 "Safety and Hygiene Manual. 


\section{QA Plan for $69 \mathrm{KV}$ Substation Project - Page 8}

All instructions, procedures, and drawings will require signed approval by appropriate Mound personnel prior to release and use.

Einal drawings with appropriate signed approvals will be required for construction.

"Field" changes during construction will be controlled in accordance with Section 1500, titled" Project Change control and configuration Review", of the Mound Project Management Manual 804.

As a minimum, written instructions and procedures will be required for the following:

$69 \mathrm{KV}$ Substation. - The instructions/procedures will include an overview of design intent, operation of the system, description of alarm systems, emergency procedures, a spare parts list, drawing list, requirements for inspection or test of replacement parts, special personnel safety considerations, potential safety hazards, and personnel training requirements/qualifications as related to $69 \mathrm{KV} / 12,470 \mathrm{~V}$ system maintenance.

\subsection{Document Control}

In order to allow unambiguous identification, the date of issue will appear on specifications and drawings. Drawings will be cataloged, handled, and filed in accordance with Mound specification SPA-891214, titled "Drawing Control Procedures".

Drawing issues will be of two types, preliminary and approved. Preliminary issues will be indicated by $0,1,2$, etc. and approved issues will be indicated by A, B, C, etc. Preliminary issues will be controlled by the Design/Build (D/B) firm and will not require approvals other than the initials of the appropriate Mound personnel. Preliminary issues will be prominently marked as such. Approval of "original" issue A of drawings will be signified by dated signatures or initials of the Design Draftsman, Checker, Project-Engineer, peer Design Reviewer, Sponsor, LP\&EC Representative, Facilities Design Drafting Manager, and others as appropriate in the Title blocks. Approval of changes to previously approved drawings (ie. issue $B$ or above) will be signified by date signatures or initials of the same functional representatives in revision blocks.

Changes in the design documents will be controlled, documented, and incorporated at the earliest practical time into a new and distinctly labeled issue of the document. The label will facilitate easy recognition of the latest issue of the document. The Project Engineer will initiate any such changes. Drawings will be changed in accordance with Manual 804, Section 1500. 


\section{QA Plan for $69 \mathrm{KV}$ Substation Project - Page 9}

\subsection{Control of Purchased Items and Services}

Potential manufacturers for all electrical equipment identified as Level 1 items in the Design/Build subproject Quality Assurance Plan will be evaluated to ascertain their capability to provide adequate quality. This evaluation will be based on utilizing manufacturers with a proven performance record; vendor site visits and evaluations; and written fabrication, inspection, and test documentation.

Written certifications of methods, composition of materials, inspection, or test results for purchased material or services identified and listed in the Design/Build subproject Quality Assurance Plan as Level 1 items during Title $I$, will be supplied by the Design/Build (D/B) firm. Any such documents will be. reviewed for completeness and adequacy by appropriate Mound personnel. All such documents will be maintained as permanent project records.

\subsection{Identification and Centrel of Ï̈ems}

Purchased items will be identified by purchase order number and receiving item number.

In order to maintain individual identity of items, manufacturer serial numbers or unique identification markings will be used to control all Level 1 items requiring written certifications.

Purchased items not requiring written certifications will be identified and controlled by established engineering practices.

The Design/Build Firm will be responsible to maintain and control all documentation and certifications relating to purchased items. The documentation will be submitted in an organized format to Mound upon final acceptance of the project.

\subsection{Control of Processes}

Qualified electricians with previous related experience must be used for all splices and terminations on cables and equipment that will operate at or above 12,470 VAC.

Written qualifications of key contract electricians used for the splices and terminations defined above will be provided by the Design/Build (D/B) firm and maintained as part of the permanent project records by Mound's Project Manager.

Note: It will be the responsibility of the Design/Build Firm to verify and document all qualifications of key subcontract electricians. 


\section{QA Plan for $69 \mathrm{KV}$ Substation Project - Page 10}

\subsection{Inspection}

In order to assure good workmanship and conformance to the design specifications and drawings, field construction in progress will be regularly inspected by the Project Engineer or by the Project Inspector responsible for construction. A daily construction logbook will be maintained as a diary of this inspection effort. The logbook will be used for notes on the progress of installation, notes on special inspections and tests, and documentation of concerns or items to be resolved.

As a minimum all splices and terminations made on cable and equipment that will operate at 12,470 VAC or higher will be inspected and tested by a project inspector that meets the. written approval of the Mound Project Engineer. Careful attention will be given to the quality of the splice and or termination. The inspector will verify that the splice and termination conforms to the requirements for medium and high voltage installations. Documentation of the inspection and test results will be maintained as permanent project records. Departures from specified requirements will be controlled in accordance with Section 5.15 of this $Q A$ Plan.

\subsection{Test Control}

Tests will be performed on the $69 \mathrm{KV}$ Substation Systems in order to demonstrate satisfactory performance for service. These tests will include the following:

Transformers: Before delivery to Mound the transformers shall be tested to ANSI C57 standards. Tests shall include resistance of all windings at all tap positions, no-load loss, total loss, impedence, exciting current, dielectric test of windings, dielectric of liquid, water content of liquid, pressure tests, ratio tests, and leakage tests. After delivery but before energization, the resistance to ground shall be tested using 1000 volt megger, dielectric tests shall be made, and resistance tests shall be made of all windings at all tap positons.

Switchgear: $15 \mathrm{KV}$ rated: Tests shall be made in compliance with ANS I C37 standards. Tests shall include resistance of all connections, operational test of all mechanical parts including springs, hipot test of all interconnecting cables.

Cables: 15kV: Continuity tests, hipot tests to ground as per Mound criteria', phasing test to conform to Mound phase rotation standard shall be performed.

Cables: 480V: Continuity tests, megger tests to ground with 1000 volt tester, phase rotation test to ensure proper operation of rotation equipment shall be performed. 


\section{QA Plan for $69 \mathrm{KV}$ Substation Project - Page 11}

All test results shall be documented and submitted to the Mound Project Engineer for approval prior to energizing any equipment.

All tests shall be performed by qualified workmen that meet the written approval of the Mound Project Engineer. The Design/Build Firm (installation activities) shall submit in writing, the qualifications of all personnel that will perform the tests.

Testing of live circuits shall comply with the provisions of 29 CFR 1910.300 through 29 CFR 1910.399, titled "Electrical Related Work Practices". The regulation to check test equipment before and after testing of live circuits shall be followed explicitly.

The results of these tests will be documented. Such documentation will include explicit identification of the items tested, the date of the test, the test set up or conditions, the test result. (quantitative if applicable), the signature of the person(s) performing the test, reference to the acceptance criteria, a statement of acceptance or rejection, and the signature of the person responsible for evaluating the test result.

A detailed test plan will be developed by the Design/Build Firm during Title $I$.

\subsection{Controi of Measuring and Test Equipment}

The certification control, and utilization of measuring and test equipment will be the responsibility of the Design/Build (D/B) firm.

Mound's Project Engineer and Project Inspector will verify that measuring and test equipment is properly utilized and is adequate to meet all testing requirements.

Mound's Standards group will act as a consultant if certification, control, or utilization of measuring and test equipment is in question.

\subsection{Handling, Storage, and Shipping}

Receiving and delivery of incoming materials will be the responsibility of the Design/Build (D/B) firm. Delivery of equipment and material will be made to the location designated on the contract drawings.

The D/B Construction Manager or a designated representative will perform receiving and inspection to confirm the identification of material, the presence of material certifications, store material, and control material. 


\section{QA Plan for $69 \mathrm{KV}$ Substation Project - Page 12}

\subsection{Inspection. Test, and Operating Status}

All items and equipment will be visually inspected by the Design/Build Construction Manager prior to installation. Any damage observed will be tagged in a visible location with an appropriate label (i.e. "DAMAGED MATERIAL DO NOT USE"). Any damage observed will be recorded by Mound's Project Inspector in the daily log. Installation of the equipment will be halted until an assessment of the damage by the manufacturer or other qualified personnel can be made. Written documentation of this assessment will be maintained by the Project Engineer. No tag will be removed without following the procedures as outlined in Section 5.15 of this manual.

All inspection and testing certifications for Level 1 items will be reviewed and verified by the Project Inspector prior to ins.tallation.

\subsection{Centrol of Nonconforming Items.}

In accordance with Section 1.5.15 of Manual MD-10241, instances of items or activities that are judged by the Project Engineer as departures fxom specified requirements (i.e. equipment, drawings or specifications) will be designated by the Project Engineer as "deviations". The nonconforming items or activities wili be-immediately marked or physically segregated to prevent inadvertent use prior to disposition. Using an Engineering Department Nonconformance Report form, the Project Engineer will provisionally classify such deviations as "major" or "minor". A major deviation will be defined as a deviation which is likely to result in an unsafe condition or prevent intended use or result. A minor deviation will be defined as a deviation which is not likely to result in an unsafe condition or to prevent intended use or result. On the Report form, the Project Engineer will also describe the deviation, state the apparent cause, and state and justify a recommended disposition. Disposition may include "scrap", "repair" or "rework", or "use as is".

The Project Engineer will then convene a Review Committee to evaluate the situation. If a major deviation is involved, then the Review Committee will consist of at least the Sponsor, the Project Engineer, the Design Engineer (if different than the Project Engineer), the Project Manager, the LP\&EC Representative, and the QA Representative. If a minor deviation is involved, then the Review Committee will consist of at least the Project Engineer and the QA Representative. In either case, other specialists may be added to the Review Committee as required. The Project Engineer will be the chairperson of the Review Committee. 


\section{QA Plan for $69 \mathrm{KV}$ Substation Project - Page 13}

The Committee will review the provisional report and disposition recommended by the Project Engineer, making any agreed changes. For major deviations, the Committee will also determine and state on the Report form the root cause and any corrective action to be taken. For minor deviations, statement of root cause and corrective action will be optional. The Committee will reach a consensus, and each member will sign the Report form.

The Project Engineer will implement the corrective action indicated by the Committee, describe the action on the Report form, and certify on the Report form that the action was taken. The QA Representative will then review the Report form and, when satisfied, will also sign the form to "close out" the deviation. As a minimum, copies of the Report will be distributed to the project file, to the QA Representative and to the appropriate Design/Build Representative. All deviations will be so resolved prior to closeout of the project.

\subsection{Corrective Action}

The Project Engineer will monitor the project for conditions adverse to quality. This will be done by noting discussions at project meetings, periodic review of the project logbook, and review of Nonconformance Reports. If adverse trends are identified or a potential exists for repetition of a major deviation, the Project Engineer will initiate corrective action. The Project Engineer will follow through to verify that the action is effective, and document any such actions and the results by use of the Engineering Department Nonconformance Report form and the procedure described in Section 5.15. The corrective action Review Committee will consist of at least the Sponsor, the Project Engineer, the Design Engineer (if different than the Project Engineer), the Project Manager, the LP\&EC Representative, and the QA Representative. Other specialists may be added to this Committee as required.

\subsection{Quality Assurance Records}

Project records will be maintained during the project execution. After drafting or editing work is completed, design drawings and controlled specifications will be stored in Drawing Control in accordance with SPA-891214, titled "Drawing Control Procedures". These procedures include storage of microfilm copies of all issues of drawings. A drawing list showing latest issues, and any operating and maintenance manuals for equipment and components will be transferred to the Sponsor after completion of the project. The following list shows other project records which will be transferred to the Engineering Systems and Design section for storage after completion of the project. 
QA Plan for $69 \mathrm{KV}$ Substation Project - Page 14

I. Project management information

a. AES, statement of scope of project, AES Cost Estimate Summary, and AES Cost Estimate Detail.

b. MSRs.

c. Work package information including scope of package, special instructions, and material list. As stated above, drawings will be stored separately in Drawing Control.

d. Project schedule, including target schedule and revisions.

e. Completed Project Quality Assurance Review and QA Plan. Audit report if project audited.

f. Monthly progress reports and other major reports.

g. Meeting minutes, important correspondence and telecon notes.

h. Project closing information, including cost summary, and reports of any preoperational readiness review, etc.

i. Any Engineering Bulletins or records of Configuration Board actions.

II. Design information

a. Design Criteria.

b. Design Calculations.

c. Specifications.

d. Completed Engineering Review Transmittal Sheets.

e. List of drawings and controlled specifications.

III. Precurement records

a. Any supplier evaluation reports.

b. Purchase Orders, any associated specifications, important correspondence, and any bid evaluation reports.

c. Supplier shop drawings if not to be stored in Drawing Control.

d. Any supplier material certifications and inspection or test reports.

VI. Eabrication and installation records

a. Project logbook.

b. Inspection reports, equipment certifications, test results, and calibration records.

c. Any nonconformance reports.

\subsection{Audits}

This project is subject to independent audit at any time by the Section $Q A^{\circ}$ Representative. The purpose of such audit would be 
to determine the degree of compliance with the provisions of this QA Plan and the adequacy of documentation of quality assurance efforts. In particular, the project hardware and files may be audited prior to transfer of the project to the Sponsor's organization.

In addition, this project is subject to independent audit by auditors from the Performance Assurance Group at Mound. Such audit would be in accordance with Manual MD-10181, titled "Mound Quality Audit Program". The procedures required by this Manual include audit reports to responsible management and provision for any necessary follow-up action. The purpose of such audit would be to determine both the degree of compliance with this $Q A$ Plan, and the adequacy and effectiveness of the QA Plan itself.

\subsection{Software}

All software used in this project will be proven, commercially available packages. Therefore, software quality assurance will not be required for this project.

When possible, all design calculations derived by a software package will be reviewed and verified. 


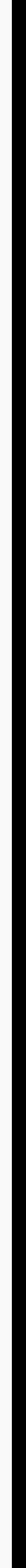


APPENDIX A

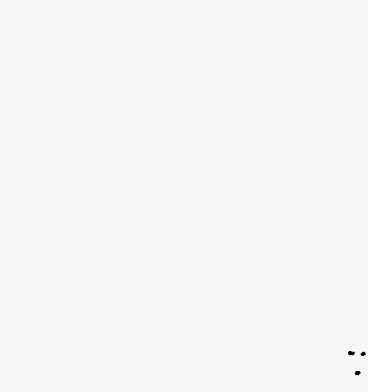

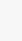




APPENDIX $B$ 



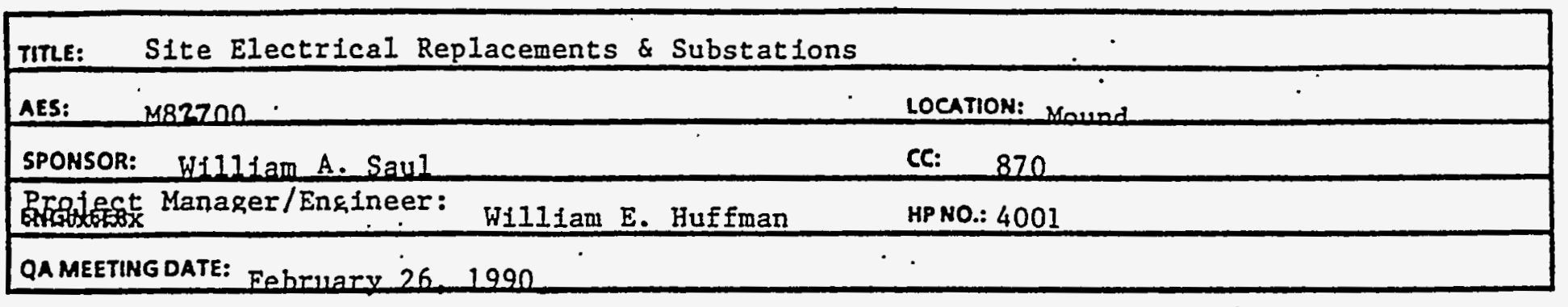

\section{PROJECT DESCRIPTION/SCOPE:}

\section{DESCRIPTION/SCOPE:}

This project consists of two (2) parts (subprojects) that will be designed to replace. key. electrical systems at Mound to ensure continuous, rellable power to production facilities. Part A, Site Electrical Replacements: consist of the replacement six (6) emiergency generators; $35 \%$ of the primary distribution cable; seven (7) PCB substations and one (1) space transformer; and the installation of two (2) tie circuit breakers. Part B: provides for the design, procurement and construction of. a new substation $(69 \mathrm{kV})$ and the fieeders (two,2).

\section{TASK RISK REVIEW, MANOR CONCERNS, \& UUSTIFICATION FOR LEVELASSIGNMENT:}

This project is considered to be normal construction and thus not subject to special concerns. However, there are seven substations to be replaced that will have to have particular care with the removal of PCB containing equipment. The level of expertise (certified) required to accomplish this is not particularly difficult to obtain and most major electrical installation operations can accomplish this activity. Should a particularly difficult removal be encountered, a QA review and possible plan generation will occur. Also, should the work effort on the emergency generators require activity involving the existing underground tanks, QA will be involved at that time. Emergency power capability to critical facilities will be maintained.

OTHER CONSIDERATIONSISPECIAL PLANS:

Action Description Memorandum are on file for Part A: $2 / 17 / \varepsilon 8$ and Part B: 11/22/88. Environmental Review of DP\&L Feeders not required:- reference DP\&L letter 2/22/90 - Willard Taylor to William E. Huffman.

\begin{tabular}{|c|}
\hline ANTICIPATED QA PROGRAM REQUIREMENT \\
\hline Level 1 \\
\hline Level 2 \\
\hline Level 3 \\
\hline
\end{tabular}

\begin{tabular}{|c|c|}
\hline APPROVALS & DATES \\
\hline 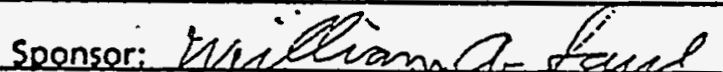 & $2 / 26 / 90$ \\
\hline 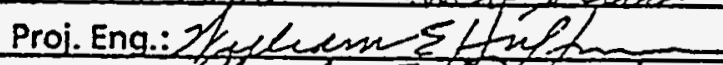 & $26 \cos \dot{0} 0$ \\
\hline Supervisor Muts $_{3}+2$ & $F E B 26,1990$ \\
\hline LP\&EC: $92 / 2,2,7 \%=$ & $26 F 5 B 90$ \\
\hline QA Engineer: Insude \&Pu & $2-26-90^{\circ}$ \\
\hline
\end{tabular}




\section{PROJECT QUALITY ASSURANCE REVIEW}

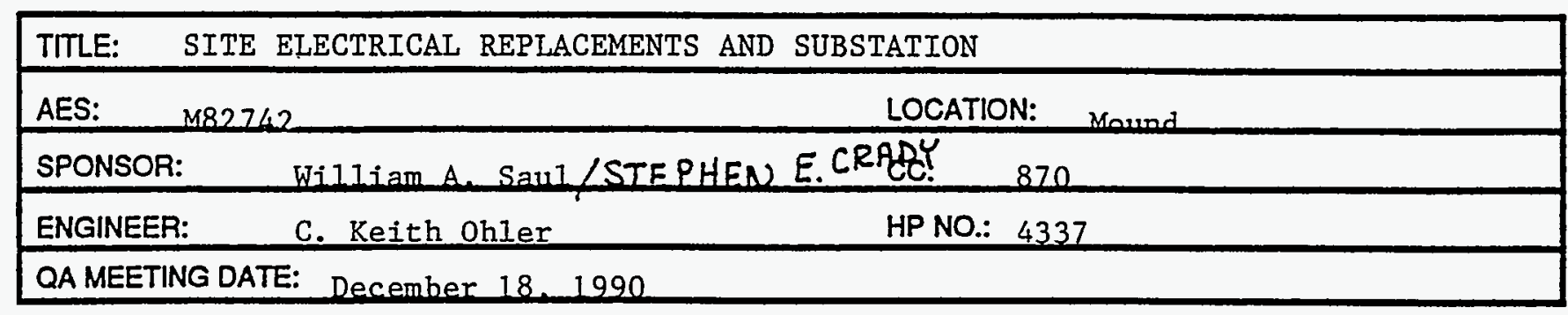

\section{PROJECT DESCRIPTION/SCOPE:}

\section{DESCRIPTION/SCOPE:}

The Site Electrical Replacements and Substation project consists of two (2) subprojects designed to replace key electrical power distribution systems at Mound. Part A, Site Electrical Replacements: consist of the replacement of six (6) emergency generators; $35 \%$ of the primary distribution cable; seven (7) PCB substations and one (1) spare transformer; and the installation of two (2) tie circuit breakerș. Part B: provides for the design, procurement, and construction of a new 69 Kilovolt substation and two (2) new primary feeders.

\section{IASK RISK REVIEW. MAJOR CONCERNS, \& JUSTIFICATION FORLLEVEL ASSIGNMENI:}

This project is considered overall to.be Quality Level 1 . The assessment is based on the risk of injury, loss of life, and loss of equipment greater than $\$ 500,000$ that may ensue if proper termination techniques and testing procedures are not followed for the high voltage installation. The problems in this area would not occur until after the system is energized. Also, an environmental risk exists by the removal of transformers containing PCB's. Appropriate EPA regulations must be followed in the removal, transportation, and disposal of the transformers.

\section{OTHER CONSIDERATIONS/SPECIALPLANS:}

Action Description Memorandums are on file for Part A: $2 / 17 / 88$ and Part B: 11/22/88. Environmental Review of DP\&L Feeders are not required: reference DP\&L letter 2/22/90 - Willard Taylor to William E. Huffman.

\begin{tabular}{|r|}
\hline ANTICIPATED QA PROGRAM REOUIREMENT \\
\hline Level $1 \quad \square$ \\
\hline Level $2 \quad \square$ \\
\hline Level $3 \quad \square$ \\
\hline
\end{tabular}

$M L-8440$

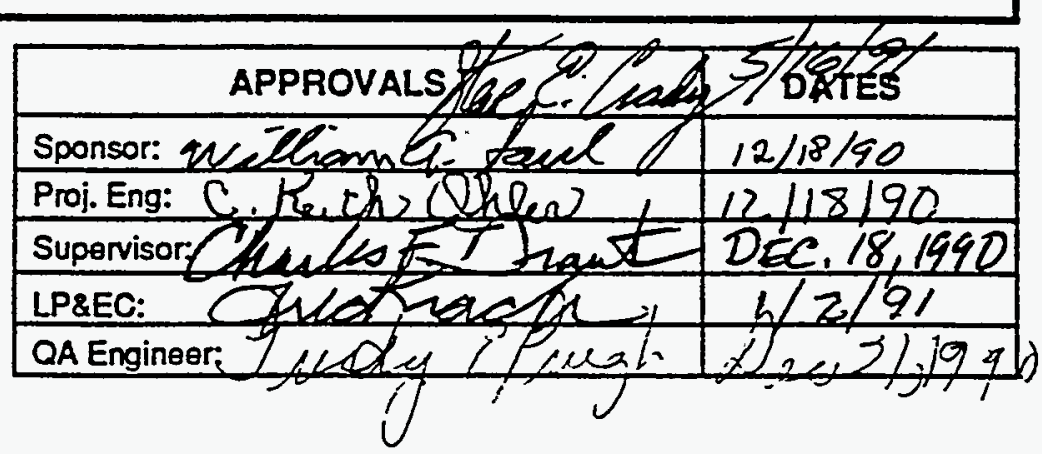

